\title{
The 15th International Conference on Human Retroviruses: HTLV and Related Viruses
}

\author{
Annemie Vandamme ${ }^{1 *}$, Luc Willems $s^{2,3^{*}}$ \\ From 15th International Conference on Human Retroviruses: HTLV and Related Viruses \\ Leuven and Gembloux, Belgium. 5-8 June 2011
}

The 15th International Conference on Human Retrovirology: HTLV and Related Retroviruses was organized in Belgium in the cities of Leuven and Gembloux from June 5 to June 8,2011 . The main topics of the meeting were human T-lymphotropic virus (HTLV), Xenotropic murine leukemia virus-related virus (XMRV) and endogenous retroviruses. The following abstracts were presented.

\begin{abstract}
Author details
'Laboratory of Clinical and Epidemiological Virology, Rega Institute for Medical Research K.U. Leuven, Leuven, Belgium. ${ }^{2}$ Cellular and Molecular Biology, Gembloux Agro-Bio Tech, University of Liège, Gembloux, Belgium.

${ }^{3}$ Cellular and Molecular Epigenetics, Interdisciplinary Cluster for Applied

Genoproteomics, University of Liège, Liège, Belgium.
\end{abstract}

Published: 6 June 2011

doi:10.1186/1742-4690-8-S1-A1

Cite this article as: Vandamme and Willems: The 15th International

Conference on Human Retroviruses: HTLV and Related Viruses.

Retrovirology 2011 8(Suppl 1):A1.

\footnotetext{
* Correspondence: annemie.vandamme@uzleuven.be; Luc.Willems@ulg.ac.be 'Laboratory of Clinical and Epidemiological Virology, Rega Institute for Medical Research K.U. Leuven, Leuven, Belgium

${ }^{2}$ Cellular and Molecular Biology, Gembloux Agro-Bio Tech, University of Liège, Gembloux, Belgium

Full list of author information is available at the end of the article
}

Submit your next manuscript to BioMed Central and take full advantage of:

- Convenient online submission

- Thorough peer review

- No space constraints or color figure charges

- Immediate publication on acceptance

- Inclusion in PubMed, CAS, Scopus and Google Scholar

- Research which is freely available for redistribution

\section{Biomed Central}

